\title{
MIGRAÇÃO DE PROJÉTIL DE ARMA DE FOGO DO CRÂNIO PARA O CANAL RAQUEANO
}

\author{
Walter C. Pereira * \\ ARNaldo G. DA Rocha *
}

A progressão de corpos estranhos pela torrente circulatória tem sido registrada com certa freqüência na literatura. Quando se trata de projéteis de armas de fogo, êstes podem ser encontrados em locais bastante distantes do ponto de penetração. O deslocamento de projéteis através do parênquima encefálico também não constitui surprêsa para os que se dedicam à traumatologia crânio-encefálica; seu pêso permite que mudem fàcilmente de posição, vencendo a resistência diminuida do tecido nervoso dilacerado. A migração de projéteis de armas de fogo da cavidade craniana para o canal vertebral é, no entanto, excepcional. Não encontramos na literatura qualquer caso em que tal fato tenha ocorrido.

\section{OBSERVAÇAO}

J.Q.S., 16 anos de idade, sexo masculino, côr branca. Registro HC 747003. No dia 23-12-1964 foi internado no Pronto Socorro do Hospital das Clínicas por ter sofrido agressão com arma de fogo. O exame clínico mostrava boas condições gerais e neurovegetativas; na região occipital direita foi encontrado o orificio de penetração do projétil. Do ponto de vista neurológico apresentava-se confuso, agitado, com hemiplegia direita parcial flácida e rigidez de nuca. O craniograma mostrou projétil localizado na fossa craniana posterior, à direita da linha média, aproximadamente na altura da cisterna magna (fig. 1). Foi adotada conduta conservadora, sendo o paciente tratado com sedativos, antibióticos e substâncias desidratantes para reduzir o edema cerebral. O quadro psiquico e a hemiplegia melhoraram considerảvelmente logo nos primeiros dias, porém os sintomas de irritação meningea se acentuaram, surgindo também hipertermia. A medicação antibiótica foi intensificada, sendo utilizadas numerosas drogas sem resultados favoráveis. Exames repetidos do liquido cefalorraqueano revelavam-se sempre alterados, evidenciando meningite inicialmente de caráter agudo, mas evoluindo depois para a cronicidade (quadro 1 ).

Em virtude da falência dos recursos clinicos para tratamento do processo meningítico, resolveu-se explorar cirùrgicamente o local atingido pelo projétil, pensando-se na possibilidade de ter-se ai formado um abscesso que, continuamente, mantinha a infecção. Nos preparativos para a intervenção cirúrgica foi feito nôvo craniograma (8 meses após o primeiro), que mostrou não estar o projétil na fossa craniana posterior. Radiografias da coluna vertebral mostraram que o mesmo ha-

Trabalho da Clinica Neurológica da Fac. Med. da Univ. de São Paulo (Prof. A. Tolosa): * Neurocirurglões. 
via deslisado pelo canal raqueano, localizando-se junto à sua parede anterior, ao nível da terceira vértebra torácica (fig. 1). Nessa ocasião o paciente apresentava, ao exame neurológico, discreta paraparesia crural motora, com reflexos aquilianos e patelares exaltados e sinal de Babinski bilateral.
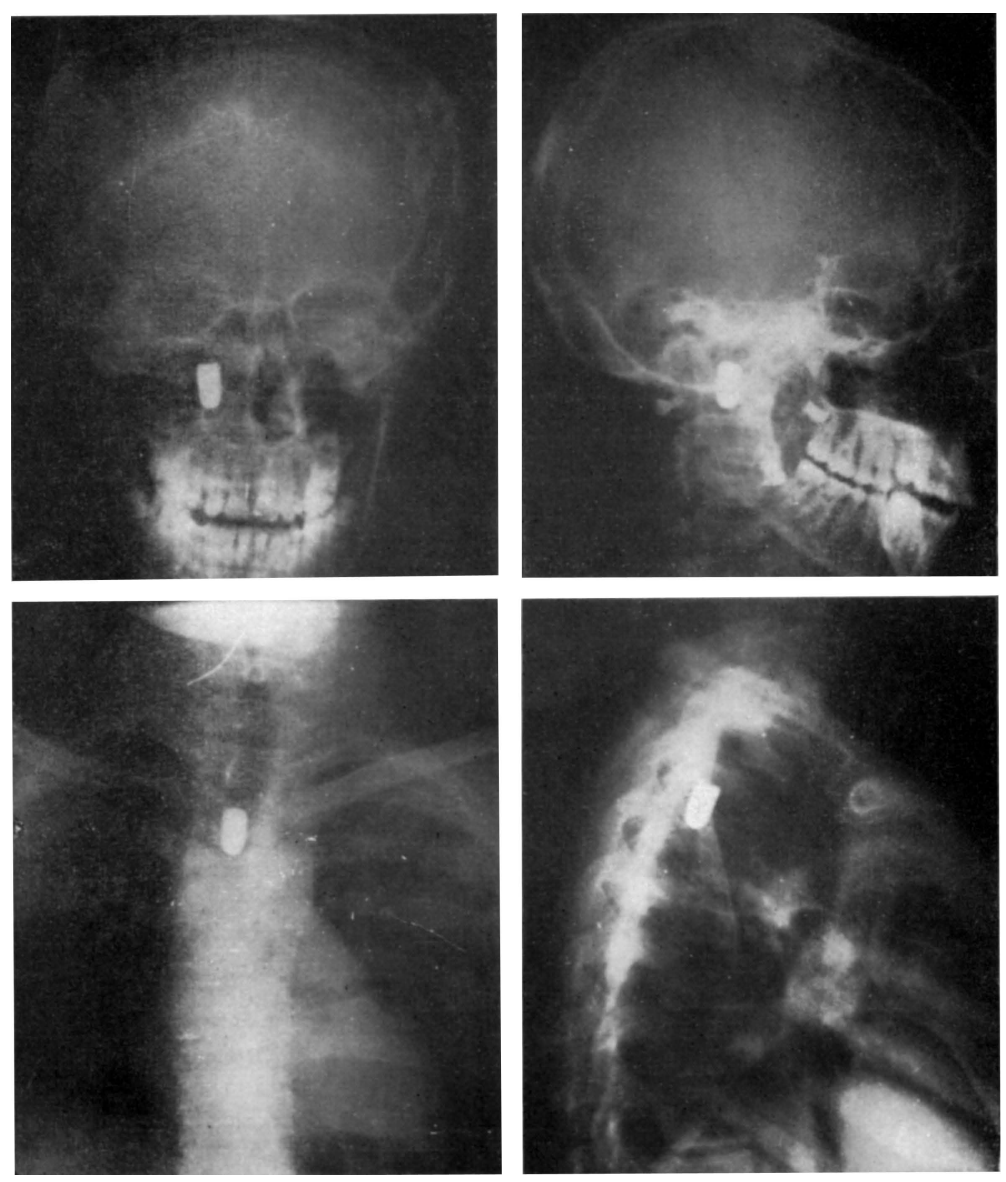

\begin{abstract}
Fig. 1 - Caso J.Q.S. Em cima, localização do projétil na fossa craniana posterior, aproximadamente ao nivel da cisterna magna. Em baixo, radiografia da coluna vertebral feita 8 meses após o acidente: observa-se o projétil situado dentro do canal raqueano, ao nivel da terceira vértebra torácica.
\end{abstract}

Em 30-8-1965 foi realizada laminectomia torácica $\left(T_{1}\right.$ a $\left.T_{4}\right)$, sendo encontrado, ao nivel de $T_{3}$, no espaço subaracnóideo da face anterior da medula, o projétil envolvido por intensa reação fibrosa (fig. 2). O corpo estranho foi removido com relativa facilidade, sem grande traumatismo do parēnquima medular. Os déficits neurológicos pré-existentes à intervenção cirúrgica não se agravaram, ocorrendo, porém, piora do quadro liquórico, que mostrou, nos primeiros dias do pós-operató- 
rio, bloqueio parcial do canal raqueano devido, provàvelmente, a edema da medula. Com o uso de corticosteróides e antibióticos houve melhora progressiva. O paciente teve alta em 11-10-1965 com o liquido cefalorraqueano pràticamente normalizado.

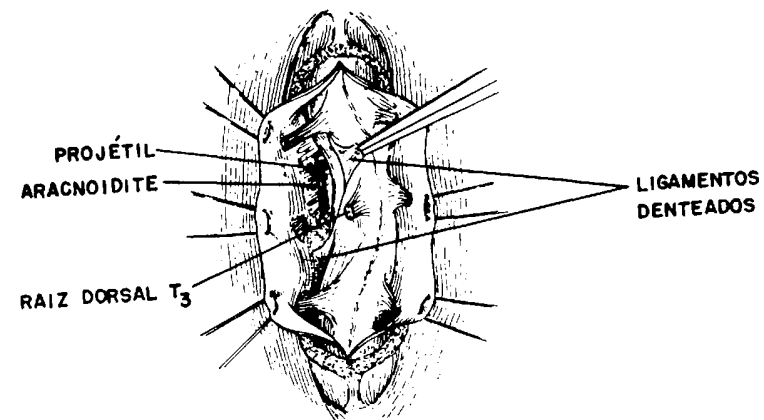

Fig. 2 - Caso J.Q.S. Esquema do ato cirúrgico, observando-se o projétil situado no espaço subaracnóideo da face anterior do canal raqueano, envolvido por intenso processo inflamatório crônico.

\begin{tabular}{|c|c|c|c|c|c|c|}
\hline$D a t a$ & $9-2-65$ & $26-3-65$ & $3-5-65$ & $11-6-65$ & $8-7-65$ & $9-8-65$ \\
\hline Local da punçāo ........ & s.o. & L. & L. & s.o. & s.o. & L. \\
\hline Leucócitos $\mathrm{p} / \mathrm{mm}^{3} \ldots \ldots \ldots$ & 2.650 & 1.500 & 320 & 448 & 104 & 96 \\
\hline Neutrófilos $\ldots \ldots \ldots \ldots$ & $85 \%$ & $70 \%$ & $2 \%$ & 0 & 0 & 0 \\
\hline Linfócitos . & $10 \%$ & $20 \%$ & $85 \%$ & $75 \%$ & $84 \%$ & $87 \%$ \\
\hline Monócitos $\ldots \ldots \ldots \ldots \ldots$ & $5 \%$ & $10 \%$ & $13 \%$ & $25 \%$ & $16 \%$ & $13 \%$ \\
\hline Proteinas $\mathrm{mg} / 100 \mathrm{ml} \ldots$ & 110 & 110 & 190 & 82 & 80 & 56 \\
\hline Cloretos $\mathrm{mg} / 100 \mathrm{ml} \ldots \ldots$ & 650 & 740 & 700 & 660 & $7: 10$ & 700 \\
\hline Glicose $\mathrm{mg} / 100 \mathrm{ml} \ldots \ldots$ & 29 & 23 & 45 & 29 & 42 & 41 \\
\hline Stookey $\ldots \ldots \ldots \ldots \ldots$ & - & $\mathrm{N}$ & $\mathrm{N}$ & - & 一 & $\mathbf{N}$ \\
\hline Cultura $\ldots . . . \ldots \ldots \ldots$ & neg. & neg. & neg. & neg. & neg. & neg. \\
\hline
\end{tabular}

Quadro 1 - Resultados dos exames do liquido cefalorraqueano feitos no pré-operatório, revelando meningite do tipo bacteriano agudo, com evolução para a cronicidade. Abreviaturas: S.O. = suboccipital; L. = lombar; $\mathrm{N}=$ normal; neg. = negativa.

\section{COMENTARIOS}

Não encontramos na literatura referências à migração de projéteis de armas de fogo da cavidade craniana para o canal raqueano, parecendo-nos, portanto, ser inédito o caso que relatamos. Além do aspecto curioso, a observação que registramos apresenta importante ensinamento: o estudo radiográfico de pacientes com ferimentos da região craniana determinados por projéteis de armas de fogo deve ser recente, quando se pretende intervir cirùrgicamente. 
Nada fazia supor neste caso que tivesse ocorrido descida do projétil para o canal vertebral. Os sintomas neurológicos tinham melhorado consideràvelmente, sendo interpretada como residual a paraparesia crural que o paciente apresentava. Os exames do liquido cefalorraqueano jamais demonstraram bloqueio do espaço subaracnóideo. A exploração cirúrgica foi indicada pela suspeita de abscesso nas proximidades do corpo estranho que estivesse fomentando a meningite rebelde a todo tratamento incruento. A repetição do craniograma foi praticada sỏmente para melhor localização do projétil e planejamento do ato operatório.

A possibilidade do deslocamento de projéteis de armas de fogo, seja dentro do próprio crânio, seja dêste para o canal vertebral, torna necessário estudo radiográfico pré-operatório recente para evitar intervenções cirúrgicas inúteis ou mesmo desastrosas.

\section{RESUMO}

É relatado um caso de migração de projétil de arma de fogo, primitivamente localizado na fossa craniana posterior, para o canal raqueano. Oito meses depois do traumatismo, uma radiografia da coluna vertebral mostrou o corpo estranho situado ao nível da terceira vértebra torácica. $O$ paciente foi submetido à laminectomia com retirada do projétil, tendo sido favorável a evolução pós-operatória. Não há caso semelhante registrado na literatura. Os autores realçam que, em casos de traumatismos cranianos causados por armas de fogo, há necessidade de exame radiológico pré-operatório recente, em virtude da possibilidade da migração dos projéteis.

\section{SUMMARY}

Migration of a bullet from the skull to the spinal canal

The authors report a case of migration of a bullet primarily located in the posterior fossa to the spinal canal. Eight months after the gunshot a X-ray showed the foreign body situated at the level of the third thoracic vertebra. The patient was submitted to a laminectomy and the bullet removed. There is not an alike case related in the medical literature. The authors emphasize the importance of a X-ray examination just before the surgery due to the possibility of the bullet migration.

Clinica Neurológica - Faculdade de Medicina da Universidade de Săo Paulo

- Caixa Postal 3461 - São Paulo, SP - Brasil. 